\title{
Integrasi Nilai-Nilai Pendidikan Multikultural Dalam Proses Pembelajaran PPKn di SMP Negeri 3 Lingsar Lombok Barat
}

\author{
Linda Agustina', Zaini Bidaya²
}

${ }^{1}$ Pendidikan Pancasila dan Kewarganegaraan, Universitas Muhammadiyah Mataram, linda.agustina10@gmail.com

${ }^{2}$ Pendidikan Pancasila dan Kewarganegaraan, Universitas Muhammadiyah Mataram, zainibidaya@gmail.com

INFO ARTIKEL
Riwayat Artikel:
Diterima: $\quad 10$-Agustus-
2018
Disetujui: 12-September-
2018

\section{Kata Kunci:}

Integrasi

nilai

multicultural

pembelajaran

\section{A. LATAR BELAKANG}

Bangsa Indonesia adalah bangsa yang kaya dengan beragam budaya, suku dan agama sehingga bangsa ini memiliki slogan Bhineka Tunggal Ika yang berarti berbeda-beda tetapi satu jua. Keberagaman budaya dan tradisi bangsa mengharuskan pemerintah lebih serius terhadap psikologi masyarakat dalam melahirkan kebijakan, termaksud kebijakan pendidikan. Hal itu disebabkan kebijakan yang di pandang bertentangan dengan kebudayaan dan tradisi masyarakat akan menjadi salah satu penyebab munculnya

\begin{abstract}
Abstrak: Integrasi nilai-nilai pendidikan multikultural yang dimaksud adalah upaya mengambungkan strategi pembelajaran yang mencangkup nilai-nilai multikultural dalam menerima dan menegaskan pada perbedaan dan kesamaan manusia yang mencangkup keragaman, ras, bahasa, agama dan gender. Tujuan dari penelitian ini yaitu untuk mengetahui bagaimana integrasi nilai-nilai pendidikan multikultural dalam proses pembelajaran Pendidikan Pancasila dan Kewarganegaraan di SMP Negeri 3 Lingsar Lombok Barat. Metode penelitian yang digunakan adalah penelitian kualitatif dengan pendekatan deskriptif. Pengumpulan data yang telah digunakan adalah observasi, wawancara, dan dokumentasi. Subyek penelitian yaitu, guru PPKn, siswa, serta kepala sekolah. Analisis data menggunakan model diskriptif melalui reduksi data, penyajian data, dan kesimpulan. Hasil penelitian menunjukkan: 1) guru PPKn melakukan pendekatan multicultural pada siswa dengan mengenalkan keragaman budaya, ras, adat, dan agama yang dimiliki siswa dikaitkan dengan lingkungan hidup siwa itu sendiri. 2) memperkenalkan bahwa keragaman budaya yang disebut multicultural itu indah, sebab dengan adanya keragaman Indonesia dikenal dan dikatakan Negara yang kaya akan multikulturalnya, dengan pendekatan tersebut, siswa dapat saling menghargai satu sama lain dan sadar bahwa indonesia merupakan negara yang kaya dengan keberagaman multikulturalnya yang digabungkan dalam bhineka tunggal ika. Sehingga sikap solidaritas sosial yang tertanam pada siswa sangat positif karna dapat menerima perbedaan-perbedaan yang berada di lingkungan sekolah dan tempat tinggal.
\end{abstract}

Abstract: The integration of the multicultural education values in question is the effort to take a learning strategy that involved the multicultural values in accepting and emphasizing the differences and similarities of people that cover diversity, race, Language, religion, and gender. The purpose of this research is to know how the integration of multicultural education values in the learning process of Pancasila and citizenship in SMP Negeri 3 Lingsar West Lombok. The research method used is qualitative research with a descriptive approach. The collection of data that has been used is observation, interviews, and documentation. The subject of the study is the teacher of PPKn, students, and the principal. Data analysis uses a discrete model through data reduction, data presentation, and conclusion. The results showed: 1) The teacher of PPKn conducted a multicultural approach to students by introducing the diversity of culture, race, customs, and religion that the students have associated with the environment of the Shiva itself. 2) introduce that the diversity of culture called multicultural is beautiful because with the diversity of Indonesia known and said to be a rich state of the multicultural, with the approach, students can appreciate each other and Aware that Indonesia is a country rich in its multicultural diversity combined in a Bhineka Tunggal Ika. So the attitude of social solidarity that is embedded in the students is very positive because it can accept the differences that are in the school environment and shelter.

ketersinggungan sosial, bahkan menciptakan konflik di tengah kehidupan masyarakat. Oleh karena itu, setiap kebijakan pendidikan perlu berbasis pada situasi dan kondisi kultural masyarakat agar implementasinya mendapatkan dukungan masyarakat, baik secara sosiologi maupun psikologis.

Di dalam pendidikan guru tidak hanya dituntut untuk menguasai dan mampu secara profesional mengajarkan mata pelajaran yang diajarkan, tetapi juga harus menanamkan nilai-nilai penting dari pendidikan multikultural di sekolah untuk menciptakan persamaan peluang pendidikan bagi semua siswa yang berbeda ras, 
etnis, kelas sosial dan kelompok budaya salah satu tujuan penting konsep pendidikan multikultual adalah untuk membantu siswa agar memperoleh pengetahuan, sikap dan keterampilan. Pluralitas bangsa Indonesia disatu sisi memang merupakan kekuatan, namun disisi lain menjadi rentan konflik bila tidak ada kesepahaman, toleransi dan saling pengertian dalam menyikapi perbedaan[1].

Hasil observasi dua faktor yang menyebabkan konflik social terjadi yaitu faktor internal dan eksternal. Dari faktor internal salah satunya kurangnya kesadaran dari diri siswa itu sendiri tentang pentingnya membina kerukunan antar teman tanpa membedakan dari manakah dia berasal, dari suku manakah dia dan lain sebagainya. Faktor ekternal salah satunya pengaruh dan lingkungan dan teman pergaulan.

Masalah tersebut terjadi karena guru tidak menerapkan pendidikan multicultural secara tuntas sehingga dapat mempengaruhi sikap perilaku siswa. Untuk itu, pendidikan diintegrasikan dengan nilai-nilai multicultural sangat penting untuk dilakukan guna untuk mencagah terjadinya konflik di antara siswa.

Pendidikan multikultural merupakan pendidikan yang memberikan peluang sama pada seluruh anak bangsa tanpa membedakan perlakuan karena perbedaan etnik, budaya, suku dan agama serta menghendaki penghormatan dan penghargaan manusia setingginya terhadap harkat dan martabat manusia dari manapun latar belakang budayanya. Dalam konteks Indonesia yang sarat dengan kemajemukkan, pendidikan ini memiliki peran yang strategis untuk dapat mengelola kemajemukan tersebut secara kreatif. Upaya membangun Indonesia yang multikultural hanya mungkin terwujud bila (1) konsep multikulturalisme menyebar luas dan dipahami pentingnya bagi bangsa Indonesia, serta adanya keinginan bangsa Indonesia pada tingkat nasional maupun lokal untuk mengadopsi dan menjadi pedoman hidupnya; (2) kesamaan pemahaman di antarapara ahli mengenai makna multikulturalisme dan bangunan konsep-konsep yang mendukungnya, dan (3) upaya-upaya yang dapat dilakukan untuk dapat mewujudkan cita-cita ini[2].

Menurut Banks menjelaskan bahwa pendidikan multikultural adalah sebagai "...as a field of study and an emerging discipline whose major aim is to create equal opportunities for students from diverse racial, ethnic, social class, and cultural group"[3]. Jadi, pendidikan multicultural terutama harus diarahkan untuk memberikan kesempatan yang sama bagi siswa dengan latar belakang ras, etnis, dan kelompokkelompok budaya.

Keberagaman budaya di Indonesia merupakan kenyataan historis dan sosial yang tidak dapat disangkal oleh siapapun. Keunikan budaya yang beragam tersebut memberikan implikasi pola pikir, tingkah laku dan karakter pribadi masing-masing sebagai sebuah tradisi yang hidup dalam masyarakat dan daerah. Tradisi yang terbentuk akan berlainan dari satu suku/daerah dengan suku/daerah yang lain. Pergumulan antar budaya memberikan peluang konflik manakala tidak terjadi saling memahami dan menghormati satu sama lain. Proses untuk meminimalisir konflik inilah memerlukan upaya pendidikan yang berwawasan Multikultural dalam rangka pemberdayaan masyarakat yang majemuk dan heterogen agar saling memahami dan menghormati serta membentuk karakter yang terbuka terhadap perbedaan[4]. Pluralitas budaya, -sebagaimana terdapat di Indonesia,- menempatkan pendidikan Multikultural menjadi sangat urgen[5].

Pendidikan merupakan salah satu media yang paling efektif untuk melahirkan generasi yang memiliki pandangan untuk dapat menjadikan keragaman tersebut sebagai bangian yang harus di apresiasi secara kontruktif. Pemahaman dan kesadaran terhadap realitas yang multikultural melalui jalur pendidikan dalam semua jenjang pendidikan tentu akan memiliki dampak yang konkrit dalam kehidupan secara luas di masa yang akan datang untuk itu pendidikan multikultural sangatlah penting dan urgen untuk di terapkan di sekolah-sekolah. Pendidikan multikultural merupakan suatu pendekatan progresif untuk melakukan transformasi pendidikan yang secara holistik memberikan kritik dan menunjukkan kelemahan-kelemahan, kegagalankegagalan dan diskrimainasi di dunia pendidikan[6].

Tujuan penelitian ini yakni untuk mengetahui integrasi nilai-nilai pendidikan multikultural dalam proses pembelajaran pendidikan pancasila dan kewarganegaraan kelas VIIIA di SMPN 3 Lingsar Lombok Barat.

\section{B. METODE PENELITIAN}

\section{Metode yang Digunakan}

Penelitian ini menggunakan penelitian kualitatif dengan pendekatan deskriptif[7]. Metode penelitian kualitatif adalah metode penelitian yang digunakan untuk meneliti pada kondisi obyek yang alamiah, (sebagai lawanya adalah eksperimen) dimana peneliti adalah sebagai instrumen kunci, tehnik pengumpulan data dilakukan secara trigulasi (gabungan), analisis data bersifat induktif, dan hasil penelitian kualitatif lebih menekankan makna dari pada geralisasi[8].

Pendekatan deskriptif digunakan untuk berupaya memecahkan atau menjawab permasalah yang sedang di hadapi pada situasi sekarang. Dilakukan dengan menempuh langkah-langkah pengumpulan data, klafikasi, analisis atau pengelolaan data, membuat kesimpulan dan laporan, dengan tujuan utama untuk membuat gambaran tentang sesuatu keadaan secara objektif dalam suatu deskriptif situasi[9]. Sementara pendapat lain menjelaskan deskriptif yaitu penelitian yang dilakukan untuk mengetahui gambaran suatu varibel, baik satu variabel atau lebih tanpa membuat 
perbandingan, atau menghubungkan dengan variabel yang lain[10].

2. Penentuan Subjek Penelitian

Penelitian yang dilakukan ini adalah penelitian kualitataif, maka subjek penelitian merupakan pihakpihak yang menjadi sasaran peneliti atau sumber yang dapat memberikan informasi yang dipilih secara purposif dengan tujuan tertentu. Subyek dalam peneliti ini adalah kepala sekolah, guru PPKn 2 orang dan siswa.

Informan dalam peneliti ini adalah kepala sekolah, wakil kepala sekolah.Alasan memilih kepalasekolah, wakil kepala sekolah, sebagai informan adalah untuk mendapatkan data-data yang lebih benar dan sesuai dengan yang terjadi di lapangan agar peneliti tidak mendapatkan data dengan mengada-ada.

Dalam penelitian kualitatif, teknik sampling yang sering digunakan adalah purposive sampling dan snowball sampling. Defenisi kedua tehnik tersebut sebagai berikut 1) Purposive sampling adalah teknik pengumpulan sampel sumber data dengan pertimbangan tertentu. Pertimbangan tertentu ini misalnya orang tersebut yang dianggap paling tau tentang apa yang kita harapkan, atau mungkin dia sebagai penguasa sehingga akan memudahkan peneliti menjelajahi obyek/situasi social yang diteliti. 2) Snowball sampling adalah teknik pengampil sampel sumber data, yang pada awalnya jumlahnya sedikit, lama-lama menjadi besar[8]. Jadi teknik pengambilan sampel dalam penelitian ini adalah purposive sampling.

3. Pengumpulan Data

Adapun pengumpulan data yang di gunakan dalam penelitian inia dalah :

\section{a. Observasi}

Observasi biasa diartikan sebagai "pengamatan dan pencatatan secara sistematik terhadap gejala yang tampak pada obyek penelitian. Gejala-gejala yang dimaksud adalah hal-hal yang berhubungan dengan Integrasi nilai-nilai pendidikan multikultural. Observasi adalah dasar semua ilmu pengetahuan. Para ilmuan hanya dapat bekerja berdasarkan data. Yaitu fakta mengenai dunia kenyataan yang diperoleh melalui observasi[11].

Dengan menggunakan metode observasi ini peneliti bisa melihat bagaimana seorang guru dengan efektif meningkatkan integrasi nilai-nilai pendidikan multikultural dalam proses pembelajaran kelas VIII $_{\mathrm{A}}$ pendidikan kewarganegaraan.

b. Wawancara

Wawancara merupakan salah satu tehnik pengumpulan data yang dilakukan dengan cara mengadakan tanya jawab, baik secara langsung maupun langsung secara bertatap muka (personal face to face interview) denga sunber data (responden)[10]. Wawancara adalah merupakan pertemuan dua orang untuk bertukar informasi dan ide malalui tanya jawab, sehingga dapat dikonstruksikan makna dalam suatu topik tertentu[12].
Beberapa macam wawancara yaitu[8]:

1) Wawancara terstruktur, digunakan sebagai tehnik pengumpulan data, bila peneliti atau pengumpul data telah mengetahui dengan pasti tentang informasi apa yang akan diperoleh. Oleh karna itu dalam melakukan wawancara, pengumpulan data telah menyiapkan intrumen penelitian berupa pertanyaan-pertanyaan tertulis yang alternatif jawabanya pun telah disiapkan.

2) Wawancara semiterstruktur, jenis wawancara ini termasuk dalam kategori in- dept interview, dimana dalam pelaksanaanya lebih bebas bila dibandingkan dengan wawancara terstruktur. Tujuan dari wawancara jenis ini adalah untuk menemukan permasalahan secara lebih terbuka.

3) Wawancara tidak terstruktur, adalah wawancara yang bebas dimana peneliti tidak menggunakan pedoman wawancara yang telah tersusun secara sistematis dan lengkap untuk pengumpulan datanya.

Metode wawancara yang digunakan oleh penulis dalam kegiatan wawancara dengan guru adalah wawancara terstruktur dan wawancara dengan siswa adalah wawancara tidak terstruktur untuk mendapatkan data-data yang diperlukan dengan mempersiapkan beberapa pertanyaan yang berkaitan dengan nilai-nilai pendidikan multikultural dalam proses pembelajaran pendidikan pancasila dan kewarganegaraan.

\section{c. Dokumentasi}

Dokumentasi hasil penelitian dari observasi atau wawancara, akan lebih kerdibel/ dapat dipercaya kalau didukung oleh sejarah pribadi kehidupan di masa kecil, sekolah, di masyarakat, dan autobiografi[13]. Hasil penelitian akan semakin kredibel apabila didukung oleh foto-foto atau karya tulis akademik dan seni yang telah ada.

\section{Analisis data}

Analisis data dalam penelitian kualitatif dan peneliti menggunakan teknik diskriptif, maka ada tiga alur kegiatan yaitu sebagai berikut[14];[15]:

\section{a. Reduksi data}

Reduksi adalah proses pemilihan, pemusatan perhatian pada penyederhanaan, pengabstraksian dan transpormasi data kasar dari catatan tertulis selama dilapangan. Untuk mereduksi data peneliti membuat ringkasan kontak, mengembangkan kategori, pengkodean dan membuat catatan refleks yang bermaksud menajamkan, menggolongkan, mengarahkan yang tidak berlaku. Kemudian mengorganisasikan sedemikian rupa sehingga kesimpulan yang tepat, ini dilakukan terus-menerus selama penelitian berlangsung. Reduksi data dilakukan kepada informan penelitian (kepala SMP Negeri 3 Lingsar Lombok Barat, guru pendidikan pancasila dan kewarganegaraan) kemudian memilih data-data yang paling penting dan yang menjadi fokus dalam penelitian kemudian 
mengelompokkannya. Dengan demikian data yang direduksi dapat memberikan gambaran yang lebih jelas.

b. Penyajian data

Penyajian data merupakan sekumpulan informasi tersusun yang memberikan kemungkinan adanya penarikan kesimpulan dan penarikan tindakan. Data teks naratif penelitian dijadikan dalam bentuk metric, diagram, jaringan, dan table yang dirancang peneliti untuk menggabungkan informasi yang diformasikan dalam bentuk sederhana dan terpadu, sehingga dapat melihat apa yang sedang terjadi. Dalam penelitian ini data yang disajikan berupa teks naratif yang mengambarkan tentang objek yang diteliti, yakni menceritakan tentang bagaimana pelaksanaan integrasi niliai-nilai pendidikan multikultural dalam proses pembelajaran pendidikan pancasila dan kewarganegaaan dan faktor yang menjadi penghambat danpendukung pelaksanaan pendidikan multikultural di SMPN 3 Lingsar Lombok Barat.

c. Kesimpulan verivikasi

Kesimpulan verifikasi merupakan upaya yang diperoleh selama pengumpulan data berlangsung. Penulis melakukan kesimpulan sejak awal pengumpulan data. Kesimpulan yang kurang jelas. Meningkatkan semakin rinci dan menyusun laporan final selesai. Untuk kesimpulan final peneliti terus mengadakan pengujian (verivikasi) selama penelitian berlangsung dengan berbagai cara antara lain meninjau ulang catatan di lapangan. Kesimpulan didapat dari data yang direduksi dan disajikan perlu juga diverifikasi dengan meninjau kembali catatan lapangan yang tersusun.

\section{HASIL DAN PEMBAHASAN}

\section{Integrasi Nilai-Nilai Pendidikan Multikultural dalam Proses Pembelajaran Pendidikan Pancasila dan Kewarganegaaan}

Proses pembelajaran dalam mengitegrasikan nilainilai pendidikan multicultural dalam proses pembelajaran PPKn dilakukan sebagaimana yang dilakukan setiap mengajar yakni menyusun perangkat pembelajaran, mulai dari materi, media, teknik pembelajaran, metode pembelajaran dan evaluasi yang dilakukan. Karena kurikulum tahun 2013 ini lebih mengedepankan sikap untuk lakukan pembinaan kepada siswa dalam setiap pembelajaran selain mata pelajaran Pendidikan Pancasila dan Kewarganegaaan. Hasil penelitian menunjukkan bahwa proses pembelajarannya yang dibagi menjadi 3 tahapan yaitu tahap awal, tahap kegiatan inti, dan tahap kegiatan akhir. Sebelum masuk pada materi berikutnya guru bertanya terlebih dahulu tentang materi yang sudah diajarkan pada pelajaran sebelumnya, kegiatan ini biasanya disebut dengan apersepsi. Ketika di bagian inti dari pembelajaran guru membagi kelompok belajar dengan tidak membedabedakan berdasarkan jenis kelamin atau bahasa atau lingkungan tempat tinggalnya, serta pada akhir pembelajaran, guru Pendidikan Pancasila dan Kewarganegaraan yang berada di kelas VIII A SMP Negeri 3 Lingsar merangkum pembelajaran dengan ikut melibatkan siswa-siswanya.
Adapun nilai pendidikan multicultural yang diintegrasikan dalam Pendidikan Pancasila dan Kewarganegaaan kelas VIIIA di SMPN 1 Lingsar Lombok Barat adalah sebagai:

\section{a. Nilai Demokrasi}

Multikultural dalam demokrasi memiliki keterkaitan dimana multikultural merupakan keragaman dan demokrasi merupakan kebebasan dalam keragaman merupakan hak mutlak yang miliki masyarakat secara keseluruhan sebagai warga Negara Indonesia.Dimana keragaman merupakan jati diri bangsa dan kekayaan bangsa.Demokrasi memiliki arti penting dalam masyarakat terutama masyarakat yang tinggal di daerah yang menganut banyak keragaman baik keragaman dari segi budaya, adat, suku, ras maupun agama.Berdasarkan adanya demokrasi memperjelas bahwa setiap masyarakat bebas dalam berbagai hal yang di katakana keragaman dan setiap masyarakat memiliki hak yang sama dalam menilai dan saling menghargai kebebasan keragaman yang masing-masing di miliki daerah lain atau masyarakat lain.

\section{b. Nilai Humanisme}

Dari segi kemanusiaan keragaman/ multikultural merupakan aspek penting dalam perkembangan kehidupan manusia yang di mana manusia lahir tidak serta menta memiliki kesamaan baik dari segi fisik, karakter, kebiasaan maupun keyakinanyang di pilih maka dari itu manusia dengan manusia lain harus dapat saling menghargai satu sama lain dikarenakan manusia lahir dengan perbedaannya masing-masing dengan perbedaan tersebut manusia dapat membedakan ciri masing-masing dan dapat saling menghargai satu dengan yang lain tidak membedakan suku, ras, adat, kebiasaan/ kebudayaan, warna kulit dan agama karna semua memiliki hak serta kewajiban yang sama sebagai warga Negara Indonesia.

\section{c. Nilai Pluralisme}

Sebagai manusia yang lahir ditengah keragaman banyak pendapat atau kelompok yang menyetujui adanya keragaman atau menerima keragaman. Hal tersebut di karenakan adanya kesadaran bahwa keragaman merupakan suatu hal yang menjadi panutan kehidupan sosial manusia dan dengan adanya keragaman manusia dapat mengenal etnik suku lain, dan budaya lain berdasarkan hal tersebut dapat menambah wawasan dan pengetahuan akan keragaman/ multikultural yang di miliki Indonesia.

Pendidikan Multikultural sangat penting dalam kehidupan berbangsa dan bernegara karena multikultural melambangkan perbedaan-perbedaan yang ada di Indonesia karena Indonesia bukan hanya satu memiliki suku, ras, budaya dan agama melainkan Indonesia ini dari sabang sampai maroeke banyak perbedaan dan disatukan dalam Bhineka Tunggal Ika.

Dalam pelaksaan integrasi nilai-nilai pendidikan multikultural dalam proses pembelajaran PPKn dapat disimak ungkapan bapak Saringin selaku kepala sekolah sebagai berikut:

"Menurut saya, pendidikan multikulturan sangat penting dalam mata pelajaran PPKn karena warga sekolah bukan hanya satu suku, 
ras, agama dan budaya melainkan sangat beragam, dengan adanya pendidikan multikultural siswa mampu saling menghargai dan menghormati satu sama lain dan akan menghindari terjadinya konflik terhadap siswa" (Informan, 25 Mei 2018)

Multikultural merupakan suatu harga mutlak bagi kehidupan sosialmasyarakat, dikarenakan multikultural menjadi suatu aspek penting dalam berkehidupan dan menjadi dasar hidup rukun dan berdampingan walaupun berbeda suku, ras, dan agama. Indonesia merupakan Negara yang dibangun berdasarka perbedaan, maka dari perbedaan itulah lahir kesatuan yang menjadi dasar Negara yang dikenal sebagai pancasila dan kokohkan dalam Bhineka Tunggal Ika, tampa adanya multicultural Indonesia tidak akan di kenal sebagai Negara yang kaya maka dari hal tersebut multikultural merupakan daya tarik tersendiri bagi Negara Indonesia.

Selain menurut Ahmad Junaeni dan Husni selaku guru PPKn di SMP Negeri 3 Lingsar Lombok Barat sebagai berikut:

"Menurut kami, dengan adanya integrasi nilainilai pendidikan multikultural didalam pelaksanaan proses pembelajaran, siswa tidak membedakan teman dalam bergaul karena siswa menjadi paham bahwa indonesia merupakan Negara yang kaya akan keberagaman atau multikultural sehingga dapat mencegah pemicu pemecahkan persatuan, dengan adanya multikultura pula dapat mempersatukan perbedaaan-perbedaan yang terjadi dalam lingkungan sekolah maupun dalam masyarakat." (Informan, 24 Mei 2018)

Nilai-nilai pendidikan multikultural dalam mata pelajaran PPKn yang disampaikan cukup beragama misalnya pernyataan berikut ini:

"menurut kami, sebagai siswa di SMPNegeri 3 Lingsar Lombok Barat kami sangat senang belajar tentang pendidikan multikultural karena kami tau bagaimana perbedaan yang terjadi tapi kita di satukan dalam bhineka tungal ika dan saling menghargai satu sama lain yang terjadi di lingkungan sekolah, keluarga, maupun masyarakat." (Informan, 24 Mei 2018)

Jadi pendidikan multikultural sangat penting di terapkan bukan hanya di lingkungan sekolah saja melainkan di lingkungan masyarakat. Konflik yang muncul diera jaman sekarang banyak yang didasari akan perbedaan, pemahaman yang tumbuh di masyarakat menyatakan bahwa perbedaan merupakan suatu hal yang akan menimbulkan kekacauan dapat dilihat dari masalah-masalah yang terjadi ditengah-tengah masyarakat karena adanya perbedaan maka banyak terjadi perselisihan.

Berdasarkan hal tersebut sebagai pendidik guru disekolah harus berperan penting dalam mengenalkan, menerapkan dan menjelaskan secara rinci akan pentingnya multikultural dalam kehidupan sehari-hari. Multikultural lahir bukan untuk menyulutkan perselisihan atau konflik antar masyarakat namun, multikultural lahir sebagai jembatan pemersatu bangsa dikarenakan indonesia sendiri merupakan negara yang lahir dari keberagaman. Untuk usia siswa penanaman multikultural harus ekstra ditanamkan pada diri siswa sebab usia siswa merupakan usia rentan akan emosi yang lebih maka sedari dini siswa harus dikenalkana akan keberagaman multikultural.

\section{Faktor Yang Menjadi Penghambat dan Pendukung Pelaksanaan Pendidikan Multikultural.}

Adapun faktor yang menjadi penghambat dan pendukung pelaksanaan pendidikan multicultural di SMP Negeri 3 Lingsar Lombok Barat adalah sebagai berikut:

a. Faktor Penghambat

Faktor penghambat pelaksanaan pendidikan multikultural diepngaruhi oleh lingkungan sekolah, sebab siswanya bukan hanya satu agama, ras, suku dan budaya akan tetapi cukup beragam terutama masalah agama dan adat istiadat siswa. Dalam lingkungan sekolah sulit menerima perbedaanperbedaan yang terdapat dalam siswa tersebut. Dengan demikian perlu adanya pendidikan multikultural, karena dalam Pendidikan Multikultural siswa dapat mengetahui perbedaanperbedaan yang terdapat dalam lingkungan sekolah dan disatukan dalam Bhineka Tungal Ika dalam mata pelajaran PPKn itu saling berhubungan antara satu dengan yang lain.

Berdasarkan pernyataan informan Saringin selaku kepala SMP Negeri 3 Lingsar Lombok Barat dapat disimak sebagai berikut :

"Menurut saya, misalkan di lingkungan tempat tinggalnya umumnya itu beragama islam tetapi tidak menjadi masalah jika kita atasi anak-anak itu kita kumpulkan, diberikan arahan dan pengertian bahwa kalian itu adalah sama tidak ada membedakan agama yang satu dengan agama yang lain" (Wawancara, 24 Mei 2018)

Dengan perbedaan agama dan adat, cara yang dilakukan oleh sekolah tersebut dengan cara memberikan pembinaan dan pemahaman pentingnya hidup bersama meskipun dalam berbeda agama ataupun suku.

Selain ungkapan dari kepala sekolah, ada juga ungkapan dari bapak Ahmad Junaeni dan Husni selaku guru PPKn dapat disimak sebagai berikut :

"Menurut kami, anak-anak masih banyak yang membedakan teman bergaul, karena mereka masih berbeda bahasa dan desa. Dengan demikian melalui pendidikan multukultural siswa dapat menyadari bahwa mereka adalah satu dan dilambangkan dalam Bhineka Tungal Ika" (wawancara, 24 Mei 2018).

Setiap pengajaran Guru di sekolah ini tetap memberikan penegasan kepada siswanya agar tetap bersemangat dalam kehidupannya dan mau menerima perbedaan yang ada di dalam masyarakat serta menjunjung tinggi nilai kebhineka tunggal ika.

Faktor penghambat lain dalam pelaksanaan pendidikan multikultural dalam mata pelajaran PPKndapat di simak sebagai berikut :

"Menurut kami, banyak yang saling tidak menghargai satu sama lain karena banyak dari teman-teman memilih teman bermain satu agama, suku,ras dan budaya. Mereka tidak menyadari bahwa mereka satu sehingga melalui pembelajaran pendidikan multikultural, kami akan menjadi lebih mengerti akan pentingnya 
pendidikan multikultural dalam kehidupan seharihari karena indonesia kaya keberagaman yang disatukan dalam bhineka tunggal ika". (wawancara, 27 Mei 2018)

Jadi perbedaan-perbedaan yang ada dilingkungan sekolah maupun masyarakat sangatlah mempengaruhi dari perkembangan siswa, faktor penghambat yang paling pertama, siswa tidak saling menghargai satu sama lain. Kedua lingkungan sekolah masih banyaknya siswa yang membedabedakan teman bergaul. Ketiga, kurangnya ketertarikan siswa akan pengetahuan multicultural.

\section{b. Faktor Pendukung}

Adapun factor pendukung dalam menerapkan pembelajaran pendidikan multicultural adalah sebagai berikut:

1) Keluarga

Faktor pendukung pelaksanaan multikultural yang pertama didapatkan dari keluarga atau orang tua, karena keluarga khususnya orang tua merupakan faktor atau unsur terdekat dalam perkembangan kehidupan anak dari didikan awal orang tualah karakter anank dapat berkembang, didikan orang tua yang mengenalkan bahwa perbedaan suku,ras,agama dan budaya bukanlah suatu penghalang untuk menjalin suatu hubungan atau kedekatan yang normal.

Jika setiap orang tua menanamkan arti akan keberagaman pada setiap anak maka tentu permusuhan/perselisihan yang sering terjadi akibat adanya perbedaan tidak akan terjadi karena kembali lagi orang tua merupakan faktor interen terpenting yang dapat mempengaruhi tumbuh kembang psikologi dan karakter seorang anak, jika didikan orang tua mengarahkan anak kearah yang baik maka seorang anakpun akan mengikuti arahan yang ditujukan oleh orang tua sebagai sekolah pertama untuk anak, orang tua harus lebih kompeten dalam mengajarkan dan membentuk karakter seseorang anak, misalnya sedari seorang anak masih kecil diajarkan tidak boleh memusuhi teman bermainnya atau tidak boleh membedakan teman-teman bermainnya orang tua harus menanamkan pada diri pribadi anak bahwa tidak boleh membedakan seseorang karena perbedaan suku, ras, budaya dan agamanya, orang tua harus berperan mengenalkan bahwa semua sama dan memiliki hak yang sama dengan pendidikan karakter yang diberikan orang tua tersebut maka anak dengan sendirinya akan terbawah hingga masa remaja dan dewasannya sebab didikan awal dari orang tua adalah penentu karakter anak kedepanya jika orang tua sampai salah menerapkan karakter anak maka tentu dikemudian hari anak akan tumbuh dengan karakter arogan dan suka bermusuhan lebih-lebih dengan teman-temannya yang berbeda darinya maka dari itu peran orang tua dalam perkembangan multikultural anak sangatlah penting sebab akan berdampak jauh kedepan untuk karakter anak.

2) Guru dan Siswa

Guru merupakan pendidik kedua setelah orang tua dari gurulah sisiwa atau anak akan mendapatkan banyak ilmu pengetahuan yang tidak dapat dari orang tua karena sarana dan prasarana yang dimiliki guru di sekolah. Pendidikan multikultural harus lebih banyak ditananamkan oleh guru karena pada lingkungan sekolah siswa/anak dapat melihat langsung keberagaman multikultural melalui tementemanya dari faktor tersebut harus benar-benar menjelaskan tentang apa multicultural dan apa manfaat multikulural tersebut, sebab jika tidak dijelaskan secara rinci maka akan menimbulkan pemahaman-pemahaman yang akan menimbulkan permusuhan antara siswa maka untuk menghindari hal tersebut guru harus pandai membimbing siswa untuk menghargai satu sama lain dan mengajarkan bahwa dengan adanya perbedaan maka negara ini atau bumi tempat mereka meminjakkan kaki ini tidak akan menyatu karena dengan perbedaan itulah dasar dari negara dibentuk dan menjadikannya satu kesatuan yang hakiki.

Guru harus menerapkan pula bahwa adanya perbedaan itu bukanlah menjadi suatu perselisihan tetapi dijadikan suatu kebanggaan akan kekayaan yang dimilki negerinya. Guru harus menjelaskan bahwa Indonesia tidak hanya kaya akan sumber daya alamnya namun dengan keberagaman manusia yang dimilikinya dengan adanya keberagaman indonesia tidak akan dikatakan negara yang kaya. Jika setiap guru menerapkan hal tersebut pada karakter siswa maka tentu siswa akan dapat lebih menghargai satu dengan yang lainnya tanpa harus merasa aneh dan berbeda dengan temannya. Di sekolahpun siswa dapat menerapkan sendiri makna dari keberagaman dan keragaman yang diterapkan guru karena sekolah merupakan tempat dimana semua eleman masyarakat berkumpul untuk menutup ilmu.Maka dari itu pendidikan perkembangan pendidikan multicultural yang diberikan guru sangat berpengaruh dalam perkembangan dan pergaulan siswa di sekolah.

\section{3) Lingkungan}

Faktor penentu dalam perkembangan multikultural pada siswa/anak adalah lingkungan, kenapa lingkungan juga menjadi faktor penentu dalam perkembangan multicultural pada anak dikarenakan lingkungan juga menjadi faktor eksternal terpenting dalam pembentukan karakter seorang anak sebab dari lingkungan pulalah anak akan bertumbuh kembang dengan melihat contoh nyata dari lingkungan hidup sekitarnya. Banyak kasus yang ditemukan sekarang, lingkungan hidup seorang anak terkadang pula akan menjadi patokan dalam berkembangannya karakter anak apalagi jika anak sedang menginjak masa remaja atau masa-masa peralihan dari kanak-kanak ke remaja, masa-masa seperti itu akan sangat mempengaruhi tumbuh kembang karakter siswa/anak.

Berdasarkan faktor-faktor pendukung pelaksanaan pendidikan multikultural di atas dapat di simpulkan bahwa aspek keluarga, guru dan lingkungan merupakan sarana penunjang terpenting dalam perkembangan karakter multikultural pada anak di karenakan pada faktor-faktor tersebut, memiliki keterkaitan dalam dalam proses perkembangan anak jika tidak adanya ketiga aspek tersebut maka anak akan tumbuh tidak mengenal apa arti dan akan berdampak tidak baik pada kehidupan social di masyarakat, perkenalan akan multikultural terhadap anak sangatlah penting akan 
usia-usia rentan anak di karenakan pada usia tersebut anak akan mencari jati diri maka dari itu perlu adanya didikan moral akan kepemahaman multikultural yang mendalam sebab banyak anak yang tidak mengenal multikultural di karenakan kurangnya akan pengetahuan akan multicultural tersebut, dan pada akhirnya anak akan memandang sebelah mata akan adanya perbedaan di sekitar lingkungannya dan anakpun akan tumbuh dan berkembang sebagai karakter yang tidak dapat menghargai orang lain lebih-lebih yang memiliki perbedaan dengan dirinya, namun berbeda jika seorang anak dari awal telah mendapatkan pengetahuan akan didikan multikultural anak akan menjadi individu yang akan mencintai keberagaman dan akan menghargai orang lain yang berbeda darinya., maka dari itu aspekaspek tersebut merupakan penunjang utama dalam pembentukan karakter multikultural pada anak.

Menurut informan menyatakan bahwa :

"Nilai-nilai pendidikan multikultural adalah kebersamaan tidak ada yang membedakan agama yang satu dengan agama lainnya sehingga melahirkan kerukunan dilingkungan sekolah maupun dalam masyarakat.

(wawancara, 25 Mei 2018)"

Dengan melihat lingkungan yang tidak sehat atau banyak mengalami perselisihan maka tidak menutup kemungkinan bahwa karakter anak pun akan terpengaruhi dengan sendirinya menjadi arogan dan tidak menghargai satu sama lainnya. Sebaiknya, untuk lingkungan sekitarnya anak harus dikenalkan akan keragaman yang ada dilingkungan hidupnya sendiri. Misalnya cara pertama, di perlihatkan tetangga ynag berbeda suku, budaya, ras dan agamanya sedang merayakan upacara hari keagamaan dan kebesarannya maka di ajarkan untuk saling menghargai dan tidak menghina perbedaan yang dimiliki orang lain bukan menjadikannya suatu perbedaan yang akan menimbulkan konflik dan cara yang kedua, dapat pula diadakan disekitar lingkungannya perlombaan yang akan memperkenalkan keberagaman multikultural seperti lomba, tari-tarian, menyanyikan lagu daerah atau memperkenalkan baju adat yang berada di nusantara, dengan menggunakan hal tersebut, anak akan lebih mengenal keberagaman multikultural yang berada di sekitar lingkungan hidupnya terlebih lagi menghargai multikultural yang ada di nusantara maka dari itu lingkungan yang ditinggali harus dilengkapi oleh masyarakat yang memiliki dedikasi dan pengetahuan akan keberagaman multicultural yang memiliki lingkungannya sebab dengan hal tersebut tumbuh kembang karakter anak akan pemahaman multikulturalpun akan menunjang karakter hidup di lingkungannya.

Informan lain juga menjelaskan bahwa :

"Faktor pendukungnya yaitu bisa dari guru, orang tua dan lingkungan, misalnya siswa diberikan pemahaman apa manfaatnya kita punya banyak teman dan tidak membedakan teman bermain dan lain sebagainya, jadi kalau sudah begitu ada modal saling menghargai dan mengormati satu sama lain jangan sampai perbedaan itu jadi terpecah belah." (wawancara, 26 Mei 2018)

Faktor pendukung pelaksanaan pendidikan multikultural sangat berpengaruh untuk berkemajuan bagi siswa dalam lingkungan sekolah karena ada beberapa faktor yang mendukung terutama pada guru,siswa dan orang tua. Dengan demikian dalam lingkungan sekolah harus saling menghargai dan menghormati untuk mempersatukan perbedaanperbedaan yang terdapat dalam pendidikan multikultural sehingga tidak ada terjadinya konflik antara satu sama lain.

Menurut peserta didik bahwa faktor pendukung dalam pelaksanaan pendidikan multikultural dalam mata pelajaran PPKn perlu teknik pembelajaran yang cocok dengan karakter siswa sehingga benar-benar dapat dimengerti oleh siswa. Hal yang di uraikan adalah:

"Kita di ajarkan saling menghargai melaluipembelajaran pendidikan multikultural dengan adanya keberagaman perbedaanperbedaan namun demikian, guru selalu mengajarkan tentang pentingnya saling menghargai satu sama lain dalam pendidikan multikultural melalui mata pelajaran PPKn".

(Wawancara, 29 Mei 2018)

Jadi pendidikan multikultural ini sangatlah penting diajarkan kepada siswa-siswi yang ada di lingkungan sekolah maupun dalam masyarakat karena pendidikan multikultural sangat berperan aktif dalam lingkungan sekitar. Multikultural merupakan jembatan pemersatu bangsa sebagaimana yang dikenal dunia Indonesia merupakan negara demokrasi yang dimana didalamnya terdapat perbedaan-perbedaan namun dengan adanya perbedaan tersebut indonesia dapat berdiri kokoh hingga saat ini.

\section{TEMUAN DAN DISKUSI}

Dengan adanya pendidikan multikultural maka siswa sebagai generasi penerus akan lebih memahami pentingnya nilai multikultural dalam berkehidupan, siswapun akan dapat saling menghargai satu sama lain dan tidak akan membeda-bedakan teman bermain. Maka hal tersebut akan mengurangi unsur konflik dalam kehidupan berbangsa dan bernegara terutama bagi para pelajar yang rentan akan konflik sesama pelajar diakibatkan kurangnya pemahaman akan multikultural. Jadi penanaman pendidikan multikultural sangatlah penting untuk modal kehidupan yang tentram dan damai.

Hal tersebut sesuai dengan hasil penelitian lain pendidikan multikultural tepat untuk membangun nasionalisme Indonesia dalam menghadapi tantangan global, karena memiliki nilai inti dalam perspektif lokal maupun global, yakni: (a) ketakwaan terhadap Tuhan Yang Maha Esa, (b) tanggung jawab terhadap Negara kesatuan, (c) penghargaan, pengakuan, dan penerimaan keragaman budaya, (d) menjunjung tinggi supremasi hukum, dan (e) penghargaan martabat manusia dan hak asasi yang universal. Tujuan dari pendidikan multikultural sangat penting bagi integrasi bangsa karena selaras dengan upaya pembangunan nasionalisme Indonesia untuk menghadapi tantangan waktu[16].

Jadi multikultural sebagai salah satu aspek penting untuk modal mendirikan bangsa terutama Indonesia yang dapat berdiri dari adanya multikultural. Dengan adanya multikultural maka siswa maupun masyarakat pada umumnya tidak akan membeda-bedakan suku, ras, budaya dan agama lain sebab hal-hal tersebut menjadi 
dasar negara yang diterapkan dalam Bhineka Tunggal Ika. Dengan adanya multikulturalpun agama yang satu akan menghargai agama yang lain, suku yang satu akan menghargai suku yang lain dan seterusnya. Hal tersebut sesuai dengan hasil penelitian lain menjelaskan bahwa sekolah memiliki fungsi, peran, dan tanggung jawab yang tinggi untuk memelihara secara terus-menerus guna mempersiapkan siswa dan masyarakat untuk mampu hidup bersama dalam keanekaragaman, tanpa menonjolkan masing-masing identitas budayanya, sekaligus juga mampu memberi jaminan hidup budaya orang lain. Oleh karena itu, pendidikan multikultural tepat untuk dipraktikkan pada tingkat pendidikan dan pendidikan tinggi[16].

\section{E. SIMPULAN DAN SARAN}

Hasil penelitian menunjukkan bahwa pelaksanaan integrasi nilai-nilai pendidikan multikultural dalam proses pembelajaran Pendidikan Pancasila dan Kewarganegaaan Kelas VIII $_{\mathrm{A}}$ di SMP Negeri 3 Lingsar Lombok Barat cukup baik di karenakan penerapan nilainilai multikultural yang dilaksanakan berdampak pada keseharian siswa, yang dapat dilihat secara langsung dari pengetahuan akan keberagaman multikultural teman sekelas, dan tidak membeda-bedakan teman bermainnya, hal tersebut membuktikan bahwa siswa kelas VIII $_{\mathrm{A}}$ memiliki karakter multikultural yang baik dikarenakan bimbingan pengetahuan multikultural yang diberikan guru dalam proses pembelajaran PPKn yang mengajarkan berbeda-beda tetapi tetap satu.

Faktor yang menjadi penghambat dan pendukung pelaksanaan pendidikan multikultural adalah faktor utama yang menjadi penghambat dalam pendidikan multikultural adalah pada siswa itu sendiri, jika siswa tidak memiliki minat/ketertarikan akan pengetahuan multicultural, maka siswa dengan sendirinya tidak akan pernah mengerti akan pentingnya multikultural dalam kehidupan sehari-harinya siswapun terkesan tidak perduli akan perbedaan yang berada disekitarnya ia pun akan menganggap bahwa, perbedaan merupakan suatu hal yang tak dapat diterima di lingkunganya dan pada akhirnya akan menimbulkan konflik berkepanjangan.

Sedangkan untuk faktor pendukungnya yaitu kemauan akan pengetahuan yang mendalam terhadap multikultural dapat menjadi penunjang dalam perkembangan multicultural pada anak. Jika anak telah mengenal dan memahami akan pentingnya multikultural, maka perbuatan-perbuatan menyimpang yang di khawatirkan terjadi pada anak, tentu tidak akan terjadi, sebab anak telah lebih dahulu memahami akan arti multikultural dan arti menghargai satu sama lainnya.

\section{UCAPAN TERIMA KASIH}

Penulis mengucapkan terima kasih kepada pihak Universitas Muhammadiyah Mataram yang senantiasa memberikan saran, masukan, dan dana kepada penulis sehingga artikel ilmiah ini selesai dengan tepat waktu.

\section{DAFTAR RUJUKAN}

[1] S. W. Danoebroto, "Model pembelajaran matematika berbasis pendidikan multikultural," J. Pembang. Pendidik. Fondasi dan Apl., vol. 1, no. 1, 2012.
[2] P. Suparlan, "Menuju masyarakat Indonesia yang multikultural," Antropol. Indones., 2014.

[3] J. A. Banks, "Developmnent Dimensions , and Callenges,” Phi Delta Kappa Int., vol. 75, no. 1, pp. 22-28, 2014.

[4] H. A. R. Tilaar and S. D. Hapsari, Multikulturalisme: Tantangan-tantangan global masa depan dalam transformasi pendidikan nasional. Gramedia Widiasarana Indonesia (Grasindo), 2004.

[5] M. A. Yaqin, Pendidikan multikultural: crosscultural understanding untuk demokrasi dan keadilan. Pilar Media, 2005.

[6] A. H. Al Arifin, "Implementasi Pendidikan Multikulutral dalam Praksis Pendidikan di Indonesia," J. Pembang. Pendidik. Fondasi dan Apl., vol. 1, no. 1, 2012.

[7] Sugiyono, Metode Penelitian Pendidikan $R \& D$. Bandung: Alfabeta, 2017.

[8] P. Sugiyono, Metode Penelitian Kuantitatif, Kualitatif, dan R\&D. 2013.

[9] M. Ali, "Muslim diversity: Islam and local tradition in Java and Sulawesi, Indonesia," Indones. J. Islam Muslim Soc., vol. 1, no. 1, p. 1, Jun. 2011.

[10] M. Abdurrahman and S. A. Muhidin, "Panduan Praktis Memahami Penelitian," Bandung CV. Pustaka Setia, 2011.

[11] S. Nasution, Berbagai pendekatan dalam proses belajar dan mengajar. PT. Bina Aksara, 2000.

[12] K. G. Esterberg, "Qualitative methods in social research," 2002.

[13] A. Sugiyono, "Pengantar Statistik Pendidikan," Jakarta Graf. Persada, 2004.

[14] M. B. Milles, "Huberman. 1984. Qualitative Data Analysis.” London: Sage Publication.

[15] M. L. Zuldafrial, "Penelitian Kualitatif," Surakarta Yuma Pustaka, 2012.

[16] Tukiran, "Pendidikan multikultural dan nasionalisme Indonesia," Sosio Didakt., vol. 1, no. 1, pp. 29-36, 2004. 